\title{
Partisipasi Politik Masyarakat Dalam Diskursus Kolom Kosong Pada Pemilihan Bupati di Kabupaten Enrekang
}

\author{
Nur Khaerah, Junaedi dan Muslimin \\ Program Studi Ilmu Pemerintahan Fakultas Ilmu Sosial dan Ilmu Politik \\ Universitas Muhammadiyah Makassar \\ Jalan Sultan Alauddin No.259, Kota Makassar \\ email: Nurkhaerah@unismuh.ac.id
}

\begin{abstract}
This article discusses Community Political Participation in the selection of regent and deputy regent candidates in the Enrekang Regency and to find out the efforts of the Empty column winning team in increasing the political articipation of the community to choose the empty column. The research method used is a qualitative descriptive method and using two kinds of data, namely primary data and secondary data.The results of this study indicate that the form of community political participation in the selection of the district Head and Deputy Regent of Enrekang district is the Electoral Activity, Lobbying, Organizational Activity, Contacting and Violence. Community participation in the electoral system and of course their have own reasons, star because of the political awareness of the community and most of them assume that choosing is the right of each individual so that everyone is free to choose according to their wishes without being influenced by others. The effort of the empty column winning team in increasing community participation to select the blank box is to focus on certain issues such as socializing the failure of the detention regent.
\end{abstract}

Keywords: Politics Participation; Empty Column; Local Election

\section{ABSTRAK}

Artikel ini membahas tentang Partisipasi politik masyarakat dalam pemilihan calon Bupati dan Wakil Bupati di Kabupaten Enrekang dan untuk mengetahui upaya tim pemenangan Kolom Kosong dalam meningkatkan Partisipasi politik masyarakat untuk memilih Kolom Kosong. Adapun metode penelitian yang digunakan adalah metode deskriptif kualitatif dengan menggunakan dua macam data, yaitu data primer dan data sekunder.Hasil penelitian ini menunjukkan bahwa bentuk partisipasi politik masyarakat dalam pemilihan Bupati dan Wakil Bupati Kabupaten Enrekang yaitu dengan Electoral Activity, Lobbying, Organizational Activity, Contacting dan Violence. Keikutsertaan masyarakat dalam sistem pemilu dan tentunya memiliki alasan masingmasing, mulai karena kesadaran politik masyarakat. Upaya Tim Pemenangan Kolom Kosong dalam Meningkatkan Partisipasi Politik Masyarakat untuk Memilih Kolom Kosong adalah dengan memfokuskan pada isu tertentu seperti mensosialisasikan kegagalan dari bupati petahana.

Keywords: Partisipasi Politik; Kolom Kosong; Pilkada 


\section{PENDAHULUAN}

Perubahan UUD 1945 telah mewujudkan konstitusi Indonesia yang memungkinkan terlaksananya penyelenggaraan negara yang modern dan demokratis (Razak \& Harakan, 2017). Pemilihan umum kepala daerah merupakan salah satu sarana pelaksana kedaulatan rakyat indonesia yang berdasarkan pancasila dan undang - undang dasar negara republik Indonesia tahun 1945, dimana cerminan pemilihan umum merupakan bukti penyelenggaraan Negara yang demokratis dan modern terlaksana. Pemilihan umum kepala daerah diselenggarakan untuk memilih calon kepala daerah yang berasal dari partai politik maupun independen.

Pemilihan kepala daerah secara serentak dilaksanakan sesuai amanat Undang-Undang No 8 Tahun 2015 tentang Pemilihan Gubernur, Bupati dan Wali Kota. Dalam Undang-Undang tersebut dijelaskan bahwa pemilihan gubernur, bupati, dan wali kota dilaksanakan secara serentak dan bertujuan untuk menghemat anggaran Negara.

Partai politik dan gabungan partai politik tidak mau mengusulkan pasangan calon semata karena merasa akan menghabiskan sumber daya, biaya, energi, waktu, dan sebagainya, secara sia-sia karena demikian kuatnya elektabilitas petahana. Begitu sulit dan rumitnya pemenuhan persyaratan bagi calon perseorangan pada pemilihan kepala daerah mengakibatkan harapan untuk tercapainya formula "setidaknya dua pasangan calon" juga sulit tercapai.

Pasangan calon tunggal ini juga sudah mendapatkan lampu hijau dari Mahkamah Konstitusi, dimana Mahkamah Konstitusi sudah mengeluarkan putusan terkait calon tunggal yang bernomor 100/PUU-XIII/2015 yang di ajukan oleh Effendi Gazali. Putusan Mahkamah Konstitusi menyatakan bahwa, "Bertentangan dengan semangat Undang-Undang Dasar 1945 jika Pemilihan Kepala Daerah tidak dilaksanakan dan ditunda sampai pemilihan berikutnya sebab hal itu merugikan hak konstitusional warga negara, dalam hal ini hak untuk dipilih dan memilih, hanya karena tak terpenuhinya syarat paling sedikit adanya dua pasangan calon kepala daerah dan calon wakil kepala daerah meskipun sudah diusahakan dengan sungguh-sungguh".

Walaupun menurut putusan Mahkamah Konstitusi tersebut dijelaskan bahwa cukup dengan memberikan pilihan kepada rakyat untuk memilih setuju atau tidak setuju, jika rakyat "Setuju" untuk memilih pasangan calon tersebut maka pasangan calon dimaksud ditetapkan sebagai kepala daerah dan wakil kepala daerah terpilih. Sebaliknya apabila ternyata suara rakyat lebih banyak memilih "Tidak Setuju" maka dalam keadaan demikian pemilihan ditunda sampai Pemilihan Kepala Daerah serentak berikutnya.

Putusan Mahkamah Konstitusi menyatakan bahwa, "Bertentangan dengan semangat Undang-Undang Dasar 1945 jika Pemilihan Kepala Daerah tidak dilaksanakan dan ditunda sampai pemilihan berikutnya sebab hal itu merugikan hak konstitusional warga negara, dalam hal ini hak untuk dipilih dan memilih, hanya karena tak terpenuhinya syarat paling sedikit adanya dua pasangan calon kepala daerah dan calon wakil kepala daerah meskipun sudah diusahakan dengan sungguh-sungguh".

Walaupun menurut putusan Mahkamah Konstitusi tersebut dijelaskan bahwa cukup dengan memberikan pilihan kepada rakyat untuk memilih setuju atau tidak setuju, jika rakyat "Setuju" untuk memilih pasangan calon tersebut maka pasangan calon dimaksud ditetapkan sebagai kepala daerah dan wakil 
kepala daerah terpilih. Sebaliknya apabila ternyata suara rakyat lebih banyak memilih "Tidak Setuju" maka dalam keadaan demikian pemilihan ditunda sampai Pemilihan Kepala Daerah serentak berikutnya.

Mahkamah Konstitusi juga beralasan ingin menjaga hak politik publik. Mahkamah Konstitusi (MK) memutus mengizinkan daerah dengan calon kepala daerah tunggal untuk menggelar pilkada serentak tahap berikutnya. Pengamat Politik Universitas Padjajaran Muradi menyebut, putusan MK merupakan bagian dari skema untuk mengupayakan hak politik publik tetap terjaga (Metrotvnews.com, Jakarta). Keputusan MK atas sengketa calon tunggal adalah bagian dari pengedepankan penghargaan atas hak konstitusi publik dalam penyelenggaraan Pemilukada. (Metrotvnews.com, Selasa 29/9/2015).

Dari seluruh Kabupaten di Provinsi Sulawesi Selatan (Sulsel) yang menggelar Pemilihan Kepala Daerah (Pilkada) 2018, terdapat satu Kabupaten yang hanya diikuti oleh satu calon. Pasangan tunggal yang telah resmi mendaftarkan diri ke Komisi Pemilihan Umum (KPU) Kabupaten Enrekang tersebut yakni pasangan calon petahana Muslimin Bando-Asman.

Pemilukada menurut peraturan pemerintah nomor 6 tahun 2005 tentang pemilihan, pengesahan, pengangkatan, dan pemberhentian kepala daerah dan wakil kepala daerah adalah sarana pelaksanaan kedaulatan rakyat di wilayah Provinsi dan Kabupaten/ Kota berdasarkan Pancasila dan Undang-Undang Dasar 1945 untuk memilih kepala daerah dan wakil Kepala Daerah. Menurut Mas'oed \&MacAndrews (2000) adalah peran serta atau partisipasi politik masyarakat secara umum dapat kita kategorikan dalam bentuk-bentuk berikut Electoral Activity, Lobbying, Organizational Activity, Contacting, dan Violence.

Calon tunggal ini dapat juga lahir karena mesin partai yang berfungsi untuk memberikan pendidikan politik bagi kader tidak berfungsi dengan baik. Karena partai selain wajib memberikan pendidikan politik kepada masyarakat juga wajib untuk memberikan pendidikan politik kepada kaderkadernya, termasuk dalam hal ini adalah dengan menyiapkan kader terbaik untuk menjadi pemimpin di daerah masing-masing serta menyiapakn kader terbaiknya untuk menjadi pemimpin di kancah nasional.

Faktor lain yang juga dapat menyebabkan lahirnya calon tunggal adalah kriteria yang diatur dalam undang-undang mengenai syarat dukungan dari jalur parpol yang naik menjadi $30 \%$ dan syarat dukungan pencalonan perseorangan yang dinaikkan lebih dari 65\%. Hal ini mungkin perlu ditinjau ulang karena masyarakat kita adalah masyarakat yang baru belajar berdemokrasi, sehingga belum siap untuk memenuhi syarat yang diatur dalam undang-undang, sehingga hal ini membuat parpol dan calon perseorangan sulit untuk maju sebagai calon dalam pilkada.

Adapun penelitian terdahulu yang telah dilakukan oleh beberapa peneliti terkait dengan partisipasi politik masyarakat dalam pilkada serentak melawan kotak kosong antara lain oleh Darmawan (2017) yang membahas tentang Peran dan Strategi kelompok "Kotak Kosong" dalam pilkada calon tunggal kabupaten Pati tahun 2017. Pada kasus pilkada di Pati ini menunjukkan bahwa peran dan strategi kotak kosong dalam pilkada hanya sekedar menguntungkan bagi anggota mereka sendiri, selain itu meningkatkan level mereka serta mempergunakan kekuasaan mereka. Disisi lain kelompok kotak kosong jga menggunakan strategi seperti membuka akses ke pembuat kebijakan, 
menggunakan strategi lobi, mengontrol informan kepada pemilihan dan juga melakukan advokasi.

Selain itu pernah dibahas pula oleh Rahmanto (2018) yang menemukan fakta bahwa calon tunggal dalam Perspektif Hak Memilih dan Dipilih di Provinsi Banten tahun 2018 menunjukkan bahwa pada pemilihan Kepala Daerah yang diikuti dengan calon tunggal sebagai wujud pelaksanaan kedaulatan rakyat yang sesuai dengan perspektif HAM. Salah satu ukuran kontestasi yang berpersektif HAM yaitu penyelenggaraannya harus menjamin ketersediaan ruang serta masyarakat juga menifestasikan kedaulatannya dalam melaksanakan haknya, baik itu hak memilih maupun hak untuk dipilih.

Terakhir, penelitian yang dilakukan oleh Angin (2017), dimana Calon Tunggal dalam Pemeilihan Kepala Daerah Di Indonesia 2017 ( Studi Kasus : Pemilihan Umum Kepala Daerah dengan Calon Tunggal di Kota Tebing Tinggi 2017) Menunjukkan bahwa Penyelenggaraan Pemilihan Kepala Daerah dengan Calon Tunggal serta langkah yang dilakukan oleh KPU Tebing Tinggi untuk mengantisipasi hal tersebut akan terulang kembali pada Pilkada selanjutnya dan dampak dari Calon Tunggal pada Pilkada Kota Tebing Tinggi 2017.

Sedangkan pada artikel ini akan focus membahas mengenai partisipasi politik masyarakat dalam pemilihan calon Bupati dan Wakil Bupati di Kabupaten Enrekang. Selain itu artikel ini juga membahas mengenai strategi dan upaya tim pemenangan Kolom Kosong dalam meningkatkan Partisipasi politik masyarakat untuk memilih Kolom Kosong.

\section{METODE PENELITIAN}

Penelitian ini dilaksanakan selama dua bulan. Adapun lokasi penelitian ini adalah bertempat di Kabupaten Enrekang dengan alasan memilih obyek lokasi penelitian tersebut adalah karena menjadi tempat terjadinya pemilihan dengan seorang kandidat petahana melawan kolom kosong. Jenis penelitian ini adalah penelitian kualitatif dengan tipe penelitian fenomenologi. Dalam melakukan pengumpulan data, peneliti mengumpulkan data primer dan data sekunder. Sumber data primer adalah sumber data utama yang digunakan untuk menjaring berbagai data dan informasi yang terkait dangan fokus yang dikaji.

Sumber data sekunder adalah sumber data pendukung yang diperlukan untuk melengkapi data primer yang dikumpulkan. Adapun menjadi informan pada penelitian ini adalah Ketua KPUD Enrekang, Tim Sukses (Kolom Kosong), Tim Sukses (Muslimin Bando-Asman), dan masyarakat Kabupaten Enrekang. Sumber data sekunder adalah sumber data pendukung yang diperlukan untuk melengkapi data primer yang dikumpulkan. Hal ini dilakukan sebagai upaya penyesuaian dengan kebutuhan data lapangan yang terkait dengan Partisipasi Politik Masyarakat (Studi kasus Kolom Kosong dalam Pilkada serentak di Kabupaten Enrekang). Data sekunder terutama diperoleh melalui dokumentasi.

Dalam pengumpulan data, peneliti menggunakan teknik Observasi, Wawancara dan Dokumentasi, sedangkan dalam menganalisis data peneliti menggunakan reduksi data, penyajian data dan penarikan kesimpulan. Untuk pengabsahan data, digunakan 3 trigulasi sumber, triagulasi data, dan triagulasi waktu. 


\section{HASIL DAN PEMBAHASAN}

Kabupaten Enrekang adalah salah satu kabupaten di Provinsi Sulawesi Selatan. Letak geografis Kabupaten Enrekang berada di jantung jasirah Sulawesi Selatan yang dalam peta batas wilayah memang bentuknya seperti jantung. Batas wilayah Kabupaten Enrekang yaitu : Sebelah Utara Kabupaten Tanah Toraja, Sebelah Timur Kabupaten Luwu, Sebelah Selatan Kabupaten Sidrap, dan Sebelah Barat Kabupaten Pinrang.

Kabupaten Enrekang terbagi menjadi 12 kecamatan dan secara keseluruhan terbagi lagi dalam satuan wilayah yang kecil yaitu terdiri atas 129 wilayah desa/kelurahan. Topografi Wilayah Kabupaten Enrekang pada umumnya mempunyai wilayah Topografi yang bervariasi berupa perbukitan, pegunungan, lembah dan sungai serta tidak mempunyai wilayah pantai. Secara umum keadaan Topografi Wilayah wilayah didominasi oleh bukit-bukit/gununggunung.

Selama setengah dasawarsa terakhir telah terjadi perubahan wilayah administrasi pemerintahan baik pada tingkat kecamatan maupun level desa/kelurahan. Pada Tahun 1995 di Kabupaten Enrekang hanya terdapat 54 desa/kelurahan yang tersebar pada 5 kecamatan. Dengan adanya perubahan situasi dan kondisi wilayah, maka pemekaran desa/kelurahan sudah menjadi keharusan. Maka pada tahun 1997, jumlah desa/kelurahan yang ada di Kabupaten Enrekang telah bertambah dari 78 desa/kelurahan kondisi tahun 1996, menjadi 108 desa/kelurahan. Demikian halnya pada tingkat kecamatan, yang semula hanya 5 kecamatan menjadi 9 kecamatan. Pada pertengahan tahun 2003 terjadi pemekaran sehingga bertambah lagi sebanyak 3 desa menjadi 111 desa/kelurahan.Kemudian pada akhir tahun 2006 terjadi pemekaran desa dan kecamatan menjadi 11 kecamatan dan 112 desa/kelurahan.Terakhir pada tahun 2008 mekar kembali menjadi 12 kecamatan dan 129 desa/kelurahan.

Ditinjau dari kerangka pengembangan wilayah maupun secara geografis Kabupaten Enrekang juga dapat dibagi kedalam dua kawasan yaitu Kawasan Barat Enrekang (KBE) dan Kawasan Timur Enrekang (KTE). KBE meliputi Kecamatan Alla, Kecamatan Anggeraja, Kecamatan Enrekang dan Kecamatan Cendana, sedangkan KTE meliputi Kecamatan Curio, Kecamatan Malua, Kecamatan Baraka, Kecamatan Buntu Batu, Kecamatan Bungin dan Kecamatan Maiwa.

Dilihat dari aktifitas perekonomian, tampak ada perbedaan signifikan antara kedua wilayah tersebut.Pada umumnya aktifitas perdagangan dan industri berada pada wilayah KBE.Selain itu industri jasa seperti transportasi, telekomunikasi, hotel, restoran, perbankan, perdagangan industri pengotahan hash pertanian berpotensi dikembangkan di wilayah tersebut. Sedangkan KTE yang selama ini dianggap relatif tertinggal bila dilihat dari ketersedian sarana dan prasarana sosial ekonomi, sangat memadai dari segi potensi SDA, sehingga amat potensial untuk pengembangan pertanian dalam arti yang luas yaitu pertanian tanaman pangan/ hortikultura, perkebunan dan pengembangan hutan rakyat.

Kabupaten Enrekang telah beberapa kali mengalami pergantian bupati sejak awal mula terbentuknya yaitu pada tanggal 1960 hingga sampai saat ini. Dari seluruh Kabupaten di Provinsi Sulawesi Selatan (Sulsel) yang menggelar Pemilihan Kepala Daerah (Pilkada) 2018, terdapat satu Kabupaten yang hanya 
diikuti oleh satu calon. Pasangan tunggal yang telah resmi mendaftarkan diri ke Komisi Pemilihan Umum (KPU) Kabupaten Enrekang tersebut yakni pasangan calon petahana Muslimin Bando-Asman.

Demokrasi sendiri dianggap sebagai suatu sistem pemerintahan yang dijalankan melalui proses pemilihan yang dilakukan secara jujur dan terbuka, dimana semua kelompok yang ikut bertarung siap menerima hasilnya sebagai suatu realitas yang harus dihormati dan dihargai oleh semua pihak. Dalam partisipasi politi ada beberapa bentuk - bentuk partisipasi politk dalam kategori salah satunya ialah Electoral Activity.

Berdasarkan hasil observasi, ada 10 informan penelitian untuk di jadikan sampel. Informan yang di ambil menunjukkan bahwa 9 orang berjenis laki-laki dan 1 orang perempuan. Dari hasil observasi informan tentang pekerjaannya atau jabatannya menunjukkan bahwa 1 Kepala Dusun, 1 wirausaha, 1 anggota KPU Enrekang bidang teknisi, 1 URT dan sisanya berjumlah 6 orang masyarakat.

Pembahasan mengenai partisipasi politik di Kabupaten Enrekang dalam bentuk Electoral Activity ialah salah satu faktor penyebab rendahnya partisipasi politik dalam momentum pemilu karena adanya pemahaman bahwa memilih adalah sebuah hak dan bukan kewajiban. Karena memilih adalah sebuah hak dan bukan kewajiban maka pemilih bisa menggunakan dan bisa juga tidak menggunakan karena tidak ada konsekuensi hukum dan moral politik bagi mereka yang tidak memilih. Partisipasi politik di Indonesia membawa tuntutan yang besar kepada perubahan sistem dan kehidupan masyarakat di Indonesia (Amaliah, Hasanuddin \& Said, 2015).

Bentuk kedua dari partisipasi politik yaitu Lobbying di mana tindakan dari individu ataupun sekelompok orang untuk menghubungi pejabat pemerintah atau pun tokoh politik dengan tujuan untuk mempengaruhi pejabat atau pun tokoh politik tersebut terkait masalah yang mempengaruhi kehidupan mereka. Partisipasi politik melalui Lobbying di Kabupaten Enrekang menunjukkan bahwa sebagian besar informan memang tidak mempengaruhi orang lain untuk memilih salah satu pasangan Calon bupati dan wakil bupati dalam Pilkada Kabupaten Enrekang 2018. Sebagian besar menganggap bahwa memilih merupakan hak masing-masing perorangan sehingga setiap orang bebas memilih sesuai keinginan mereka tanpa dipengaruhi orang lain.

Bentuk ketiga partisipasi politik yaitu Organizational activity di mana keterlibatan warga masyarakat ke dalam berbagai organisasi sosial dan politik. Partisipasi politik di Kabupaten Enrekang menunjukkan bahwa sebagian besar masyarakat tidak berpartisipasi politik dalam bentuk menjadi tim sukses salah satu pasangan Calon bupati dan Calon wakil bupati. Akan tetapi dilihat dari keaktifan laki-laki dan perempuan, maka dalam hal ini perempuan cenderung lebih aktif. Sebagai tim sukses, seperti berusaha untuk mempengaruhi orang lain untuk memilih pasangan Calon bupati dan wakil bupati yang ia wakili. Akan tetapi, untuk yang pernah menjadi tim sukses relawan sementara, hanya sempat membagikan stiker dan tanggalan karena sebagai istri PNS ia mengaku tidak diijinkan untuk menjadi tim sukses dan diharuskan bersifat netral.

Bentuk partisipasi politik ke empat yaitu contacting di mana partisipasi yang dilakukan oleh warga negara dengan cara langsung misalnya melakukan komunikasi untuk membangun jaringan kerjasama. Partisipasi politik melalui contacting di Kabupaten Enrekang menunjukkan bahwa partisipasi politik 
dalam Pilbup yang berbentuk memperbincangkan atau mendiskusikan perihal seputar Pilkada Kabupaten Enrekang 2018. Bagi sebagian yang mendiskusikannya, diantaranya memperbincangkan dengan keluarga maupun rekan kerja. Sedangkan intensitasnya tidak rutin, tetapi pada saat-saat menjelang Pilkada biasanya lebih sering memperbincangkannya.

Bentuk partisipasi politik yang ke lima adalah violence di mana cara-cara kekerasan untuk mempengaruhi pemerintah Partisipasi politik melalui violence di Kabupaten Enrekang menunjukkan bahwa tidak ada unsur kekerasan dalam pemilihan calon bupati dan wakil bupati hanya dalam kampanye sebagian masyarakat tampaknya menganggap bahwa mengikuti kampanye itu tidak penting dan sebagian yang lainnya tidak mengikuti kampaye karena dibatasi oleh peraturan bahwa pegawai negeri sipil harus netral. Sementara itu pihak juru kampanye sendiri mengakui bahwa memang antusiasme masyarakat dalam mengikuti kampanye sangat rendah. Hal itu dikarenakan cara berkampanye yang kurang efektif sehingga bagi sebagian masyarakat dianggap kurang bermanfaat.

Pemilihan Bupati dan Wakil Bupati di Kabupaten Enrekang tahun 2018 sebagian besar partisipasi politik masyarakat tergolong partisipasi politik aktif namun pragmatis, hal tersebut lebih dipengaruhi oleh faktor psikologis baik dari internal ataupun ekseternal dari pemilih. Pragmatisme jangka pendek pemilih cenderung terbentuk akibat kurang kritis terhadap isu-isu serta adanya kompensasi instan yang ditawarkan oleh kandidat. Selembar uang, sebungkus sembako dan berbagai praktik lainnya mereka rasakan sudah cukup untuk menukar suara mereka.

\section{PENUTUP}

Kabupaten Enrekang merupakan salah satu dari sebelas kabupaten di Sulawesi Selatan yang mengikuti pilkada serentak. Dinamika politik di dalam pilkada Kabupaten Enrekang sangat tinggi dimana dalam pilkada Kabupaten Enrekang ini yang ikut bertarung dalam pemilihan kepala daerah merupakan petahana. Selain itu juga terdapat kolom kosong tetapi tetap gagal meraih kemenangan.

Hasil penelitian yang dilakukan di Kabupaten Enrekang menghasilkan kesimpulan sebagai berikut: bentuk-bentuk partisipasi politik masyarakat Kabupaten Enrekang pada pemilihan Bupati dan Wakil Bupati adalah Electoral Activity, Lobbying, Organizational activity, Contacting dan Violence. strategi Tim Kolom Kosong dalam Pilkada Kabupaten Enrekang Tahun 2018 adalah menggunakan strategi lobby, pengumpulan massa, peran media sosial dan melakukan advokasi.

\section{REFERENSI}

Alichia, Yashinta Putri. 2013. "Pengaruh Ukuran Perusahaan, Pertumbuhan Perusahaan, Dan Opini Audit Tahun Sebelumnya Terhadap Opini Audit Going Concern (Studi Empiris Perusahaan Manufaktur yang terdaftar pada Bursa Efek Indonesia)". Skripsi/Tesis Fakultas Ekonomi Universitas Negeri Padang.

Amaliah, A. N., Hasanuddin, M., \& Said, A. (2015). Partisipasi Politik Masyarakat Miskin Kota Dalam Pemilihan Presiden Dan Wakil Presiden 2014 di Kota Makassar. Otoritas: Jurnal Ilmu Pemerintahan, 5(1). 
Arbi Sanit (2012), Perwakilan Politik Indonesia, CV. Rajawali, Yogyakarta,

Ardial, 2010. Komunikasi Politik, Jakarta : Indeks

Astomo, Putera. (2014). Perbandingan Pemikiran Hans Kelsen Tentang Hukum Dengan Gagasan Satjipto Rahardjo Tentang Hukum Progresif Berbasis Teori Hukum. Semarang: Yustisia Edisi 90.

Budiyanto. 2007. Dasar-Dasar Ilmu Tata Negara. Jakarta: Erlangga.

Cangara, Hafied. 2011. Komunikasi Politik Konsep, Teori, dan Strategi. Jakarta: PT. Raja Grafindo Persada.

Darmawan, Ikhsan.2017. Peran Dan Strategi Kelompok "Kotak Kosong” Dalam Pilkada Calon Tunggal Kabupaten Pati Tahun 2017: Studi Pendahuluan. Jurnal Ilmu Politik. Vol 2, No. 2

Fadjar. 2010. Perkembangan \& Kondolidasi Lembaga Negara Pasca Reformasi.

Firmanzah. 2012. Marketing Politik Antara Pemahaman Dan Realitas. Jakarta: Yayasan Pustaka Obor Indonesia

HR, F. S., \& Harakan, A. (2017). Eksklusivitas Adat Dalam Bingkai Demokrasi di Indonesia. Jurnal Agregasi, 5(1).

Janedri M. Gaffar, 2013, Demokrasi dan Pemilu di Indonesia, Jakarta: konstitusi Pers, hlm 5

Kelsen, Hans, 2007, Teori Hukum Murni : Dasar-dasar Ilmu Hukum Normatif, Penerbit Nusamedia, Bandung.

Mardikanto, Totok dan Poerwoko Soebiato. 2013. Pemberdayaan Masyarakat Dalam Perspektif Kebijakan Publik. Bandung : Alfabeta.

Munir. 2009. Pembelajaran Jarak Jauh Berbasis Teknologi Informasi dan Komunikasi. Bandung: Alfabeta.

Perangin Angin, Riski Sari. (2017). Calon Tunggal dalam Pemeilihan Kepala Daerah Di Indonesia 2017 ( Studi Kasus : Pemilihan Umum Kepala Daerah dengan Calon Tunggal di Kota Tebing Tinggi 2017). Skripsi di Terbitkan. Departemen Ilmu Politik. Universitas Muhammadiyah Makassar.

Peraturan pemerintah nomor 6 tahun 2005 tentang "pemilihan, pengesahan pengangkatan, dan pemberhentian kepala daerah dan wakil kepala daerah

Rahmawati Yuri Toni. 2018. Calon Tunggal Dalam Perspektif Hak Memilih dan Dipilih di Provinsi Banten. Jurnal HAM, Vol 9, No 2.

Roni Wiyanto. 2014, Penegakan Hukum Pemilu DPR, DPD, DPRD, Bandung: Mandar Maju, hlm 3.

Sugiyono. 2012.Metode Penelitian Bisnis. Bandung : Alfabeta.

Surbakti, Ramlan. 2010. Memahami Ilmu Politik. Gramedia Pustaka Utama. Jakarta.

Undang - undang No.22 Tahun 2007 tentang Penyelenggara Pemilihan Umum.

Undang-Undang Republik Indonesia Nomor 23 Tahun 2014 Tentang Pemerintahan Daerah.

Venus, Antar (2007). Manajemen Kampanye: Panduan Teoretis dan Praktis dalam Mengefektifkan Kampanye Komunikasi. Bandung : Simbiosa Rekatama Media.

Wazir . 2009. Panduan Penguatan Manejemen Lembaga Swadaya Masyarakat. PT. Rineka Cipta. Jakarta 